\title{
Insulin Receptor Deficiency in
}

\section{Genetic and Acquired Obesity}

\author{
Andrew H. Soll, C. Ronald Kahn, David M. Neville, Jr., and \\ JESSE RoTH \\ From the Diabetes Branch, National Institute of Arthritis, Metabolism, and \\ Digestive Diseases, and the Section on Biophysical Chemistry, Laboratory of \\ Neurochemistry, National Institute of Mental Health, National Institutes of \\ Health, Bethesda, Maryland 20014
}

\begin{abstract}
A B S T RAC T We have previously shown that in the insulin-resistant obese hyperglycemic mouse (ob/ob) there is a deficiency in the number of insulin receptor sites on hepatocytes, adipocytes, and thymic lymphocytes. We now find that concentration of insulin receptors on liver plasma membranes is decreased in the $\mathrm{db} / \mathrm{db}$ mouse, another form of inherited obesity, and in normal mice that became obese after treatment with gold thioglucose, while thin mice, heterozygous for the ob mutation (ob/ + ), have normal insulin binding. With acute and chronic food restriction of the ob/ob and gold thioglucose obese mice, there is reduction in hyperinsulinemia and an associated increase in the insulin receptor concentration toward normal. In contrast, when fasting ob/ob mice were given exogenous insulin to maintain the hyperinsulinemia, insulin receptors failed to increase. Thus, in all cases, there was a consistent relationship between the degree of hyperinsulinemia and of insulin receptor loss. These findings suggest that decreased insulin binding is a characteristic feature of the insulin resistance of obesity, and that sustained hyperinsulinemia is a major factor in the control of the concentration of insulin receptors on target cells.
\end{abstract}

\section{INTRODUCTION}

Resistance to the action of both endogenous and exogenous insulin has been found in spontaneous and induced obesity in rodents and in man $(1,2)$. In recent years it has become possible to measure directly and quanti-

This work has been presented in part at the National Meeting of the American Federation for Clinical Research in Atlantic City, N. J., April 1973 and at the Conference on Obesity, Fogarty International Center, Bethesda, Md. October 1973.

Received for publication 20 August 1974 and in revised form 19 May 1975. tatively the interaction of insulin with its receptors on surface membranes of several target tissues (3). When we applied these techniques to the study of the obese hyperglycemic mouse (ob/ob) we found decreased binding of insulin to its specific receptors in liver (4, 5 ), a finding that correlates well with the hepatic insulin resistance which these animals exhibit (6). We have previously shown that the decrease in insulin binding to liver membranes of the ob/ob mouse is not due to occupation of receptor sites by endogenous insulin $(4,5)$ but is fully accounted for by the decrease in concentration of insulin receptors; the receptors that remain are normal with respect to affinity for insulin, kinetics of association and dissociation, biological specificity, and the cooperative interaction between receptor sites (7). Furthermore, the decrease in the insulin receptor concentration is a specific alteration with no change in receptors for glucagon, growth hormone, or catecholamines and no detectable change in plasma membrane structure or function $(4,5)$. Decreased insulin binding to receptors is also found in fat (8), muscle (9), and thymic lymphocytes of ob/ob mice (10).

In the present study we have sought to determine $(a)$ whether the decrease in insulin binding is limited to the ob mutation or is common to other forms of obesity and $(b)$ what factors control the insulin receptor in obesity. We find that insulin receptors are also decreased in another model of inherited obesity, the $\mathrm{db} / \mathrm{db}$ mouse, and in acquired obesity induced by treatment with gold thioglucose. Furthermore, thin mice that are heterozygous for the ob mutation have normal insulin binding. In acquired obesity, the decrease in insulin receptors becomes more pronounced with increasing obesity. Under conditions of dietary manipulation and insulin administration, we find a close correlation be- 
tween the degree of chronic hyperinsulinemia and the insulin receptor deficiency.

\section{METHODS}

ob/ob Mice. C57BL/6J mice were purchased from Jackson Laboratories, Bar Harbor, Me., in four groups: mice homozygous for the ob gene (ob/ob), their thin littermates (one-third normal and two-thirds heterozygote), known heterozygotes $(o b /+)$, and normal mice $(+/+)$. Mice homozygous for the ob/ob gene were of significantly greater body weight than thin animals by 4 wk of age. Thin littermates, known heterozygotes, and normal $\mathrm{C} 57 \mathrm{BL} / 6 \mathrm{~J}$ mice of equal age could not be distinguished from one another by body weight, plasma glucose, plasma insulin, or insulin binding to receptors (vide infra). Therefore for most experiments, data from these three groups were combined as thin controls.

(d)/ab Mice. C57BL/KsJ mice from the same source were either normal $(+/+)$ or homozygous for the $\mathrm{db}$ gene $(\mathrm{dlb} / \mathrm{db}) . \mathrm{db} / \mathrm{db}$ mice were studied during the first $3 \mathrm{mo}$ of life. During this time they are very similar to the ob/ob mice in their obesity, hyperglycemia, hyperinsulinemia, and insulin resistance (11).

Gold thioglucose obese mice. Mice treated with gold thioglucose (gift of Schering Corp., Kenilworth, N. J.) were from the C57BL/6J $(+/+)$ strain and received an intraperitoneal injection (0.4-0.5 $\mathrm{mg}$ per $\mathrm{g}$ body wt) at $4-6$ wk of age. Gold thioglucose, which has a direct toxic effect on the ventromedial hypothalamus, induces hyperphagia and obesity in normal mice (12). Of our treated mice, one-third died in the 1st wk after treatment, onethird remained normal in body weight (hereafter called gold thioglucose thin), and one-third became obese (hereafter called gold thioglucose obese). At 10-30 wk after the gold thioglucose, the obese mice were $160-250 \%$ of the body weight of the controls.

Except when noted otherwise, all mice had access to Purina Rat Chow (Ralston Purina Co., St. Louis, Mo.) ad lib. until the time of sacrifice (8-10 a.m.). Age- and sex-matched controls were used for each experiment. Plasma glucose was measured by the glucose oxidase method (13). Immunoreactive insulin in plasma (IRI) ${ }^{2}$ was measured by radioimmunoassay (14); porcine insulin (purchased from Eli Lilly and Company, Indianapolis, Ind.) was used as standard to measure exogenously administered hormone and mouse insulin (gift of J. Schlichtkrull, Novo Research Institute, Copenhagen) was used as a standard to measure endogenous hormone. By radioreceptor assay, the mouse standard appeared to be of slightly decreased potency and therefore the insulin concentrations are probably overestimated by two- to threefold (7).

The fully purified plasma membrane fraction of liver was prepared as previously described (step 15, reference $15)$. Using this method we have shown that there is no differential selection of liver membranes from obese mice when compared to thin ones (16). [ $\left.{ }^{125} \mathrm{I}\right]$ Porcine insulin was prepared at a specific activity of $80-180 \mu \mathrm{Ci}$ per $\mu \mathrm{g}$ by a modification (17) of the chloramine-T method (18) and separated from free $\mathrm{I}^{-}$by chromatography on a cellulose column (19). Monoiodoinsulin has been previously shown to be biologically active (20) and interacts with the receptor in a manner indistinguishable from native insulin. ${ }^{2}$ Greater ${ }^{1}$ Abbreviation used in this paper: IRI, immunoreactive
insulin concentration in plasma.

${ }^{2}$ Kahn, C. R., P. DeMeyts, and J. C. Sodoyez. Unpublished observations. than $90 \%$ of the $\left[{ }^{125} \mathrm{I}\right]$ insulin prepared by this technique is bound in the presence of an excess of membranes.

The binding of $\left.{ }^{125} \mathrm{I}\right]$ insulin $\left(0.1 \mathrm{ng}\right.$ per $\mathrm{ml}$ or $1.7 \times 10^{-11}$ $\mathrm{M}$ in all experiments) to the liver membrane fraction was performed directly in Beckman microfuge tubes (Beckman Instruments, Inc., Fullerton, Calif.) with an incubation period of $6 \mathrm{~h}$ at $20^{\circ} \mathrm{C}$, as previously described (7). The membrane-bound $\left[{ }^{125} \mathrm{I}\right]$ insulin was sedimented by centrifugation; the tips of the tubes which contain the pellet of membranes were excised and counted in a gamma counter. Nonspecific binding, defined as the radioactivity associated with the membrane pellet in the presence of $50 \mu \mathrm{g}$ per $\mathrm{ml}$ unlabeled insulin, was less than $10 \%$ of total binding in all experiments and was subtracted from the total of $\left.{ }^{125} \mathrm{I}\right]$ insulin binding to yield specific binding (21). Membrane protein concentration was determined by the Lowry technique (22) using bovine serum albumin as a standard. An

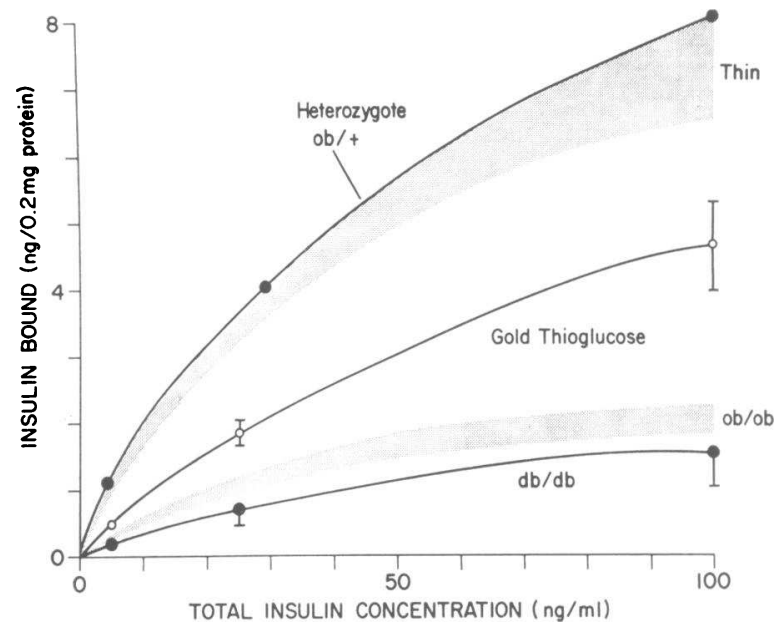

Figure 1 Insulin binding to mouse liver membranes in ob/ $\mathrm{ob}, \mathrm{db} / \mathrm{db}$, gold thioglucose obese mice, and in mice heterozygous for the ob gene. The indicated groups of mice were fed ad lib. until sacrifice. Liver membranes were prepared and incubated with $\left.{ }^{125} \mathrm{I}\right]$ insulin at $0.1 \mathrm{ng}$ per $\mathrm{ml}$ and unlabeled insulin over the range of $0-50,000 \mathrm{ng}$ per ml. After $6 \mathrm{~h}$ at $20^{\circ} \mathrm{C}$, triplicate samples were centrifuged, and the radioactivity in the membrane pellet counted. Radioactivity that was bound to the membrane pellet in the presence of excess unlabeled insulin $(50,000 \mathrm{ng}$ per $\mathrm{ml})$ was considered to be "nonspecific binding." Specific $\left[{ }^{125} \mathrm{I}\right]$ insulin binding was calculated by subtracting the "nonspecific binding" from the total binding at each insulin concentration and was then normalized to a membrane concentration of $0.2 \mathrm{mg} / \mathrm{ml}$. The specific insulin bound is plotted as a function of the total insulin concentration. Data for the thin mice are the mean \pm SEM of triplicate determination in 19 experiments on 10 different preparations of liver membranes and for the ob/ob mice from 15 experiments on 7 membrane preparations. The $\mathrm{db} / \mathrm{db}(\bullet)$ and gold thioglucose obese mice $(O)$ shown for example are the groups designated $\mathrm{db} / \mathrm{db}-\mathrm{II}$ and gold thioglucose (GTG-I) in Table I. For the latter two groups of mice and the heterozygote ob mice, the data are the mean \pm SEM of the data in three experiments. Data for the thin controls for the $\mathrm{db} / \mathrm{db}$ and gold thioglucose mice fell within the range of the thin controls for the ob/ob mice and therefore all of the thin controls were considered as one group. 
TABLE I

Metabolic Data for the $d b / d b$ and Gold Thioglucose-Treated Mice

\begin{tabular}{lcccc}
\hline \multicolumn{1}{c}{ Experiment } & Mean body wt & Plasma glucose & Plasma IRI & Insulin bound* \\
\hline & $g$ & $m g / 100 \mathrm{ml}$ & $n \mathrm{~g} / \mathrm{ml}$ & fmol/mg protein \\
I. db/db-I & $36.6 \pm 1.3$ & $215 \pm 18$ & $13.0 \pm 4.1$ & $15.9 \pm 0.4$ \\
Thin littermates $\ddagger$ & $18.1 \pm 0.4$ & $132 \pm 8$ & $1.0 \pm 0.2$ & $29.9 \pm 3.7$ \\
II. db/db-II & 39.0 & - & - & $8.3 \pm 2.1$ \\
Thin littermates & 22.8 & - & - & $25.9 \pm 1.1$ \\
III. GTG-I & $47.0 \pm 1.0$ & $169 \pm 47$ & $48.0 \pm 14.0$ & $12.8 \pm 1.9$ \\
Thin littermates & $27.6 \pm 0.7$ & $122 \pm 8$ & $3.7 \pm 0.4$ & $24.8 \pm 2.7$ \\
IV. GTG-II & $39.0 \pm 2.9$ & $186 \pm 47$ & $6.2 \pm 1.0$ & $19.8 \pm 0.7$ \\
GTG-II dieted§ & $24.6 \pm 0.4$ & $126 \pm 21$ & $0.6 \pm 0.2$ & $27.8 \pm 3.7$ \\
GTG-II no weight gain & $26.3 \pm 0.3$ & $152 \pm 11$ & $0.9 \pm 0.1$ & $27.4 \pm 1.4$ \\
Thin littermates & $24.9 \pm 0.8$ & $131 \pm 14$ & $1.2 \pm 0.3$ & $27.7 \pm 2.3$ \\
\hline
\end{tabular}

* Insulin binding was determined at an insulin concentration of $0.1 \mathrm{ng}$ per $\mathrm{ml}\left(1.7 \times 10^{-11} \mathrm{M}\right)$ and corrected to a membrane protein concentration of $0.2 \mathrm{mg}$ per $\mathrm{ml}$.

$\ddagger$ Thin littermates were age and sex matched for the appropriate groups.

$\S$ The group designated GTG-II dieted weighed $35.1 \mathrm{~g}$ at $14 \mathrm{wk}$ of age and was then restricted to $4 \mathrm{~g}$ of Purina Rat Chow; the weight at $18 \mathrm{wk}$ is indicated.

attempt was made to use $0.2 \mathrm{mg}$ of membrane protein per $\mathrm{ml}$ in all experiments. Since small variations in membrane concentration did occur, the observed specific $\left[{ }^{125} \mathrm{I}\right]$ insulin binding was normalized to this value (7). Unless otherwise noted, the binding data presented in each table and figure represents separate experiments on different membrane preparations.

\section{RESULTS}

I. Decreased insulin receptors in obesity. As previously reported (5), the binding of insulin to liver membranes of the ob/ob mouse was consistently found to be $25-35 \%$ of that observed in the thin animals (Fig. 1). Similarly, in two groups of $\mathrm{db} / \mathrm{db}$ mice that were studied while hyperinsulinemic, insulin binding was decreased to about the same degree as that observed in the ob/ob mice (Fig. 1, Table I), and in two groups of mice that became obese and hyperinsulinemic after treatment with gold thioglucose, insulin binding was decreased to $50-70 \%$ of control (Fig. 1, Table I). Mice that were treated with gold thioglucose but did not become obese had normal insulin binding (Table I).

As had been demonstrated earlier for the ob/ob mouse (7), analyses of these data showed that the decrease in insulin binding in each of the obese mice was fully accounted for by a decrease in the insulin receptor concentration. When insulin bound is plotted as a function of hormone concentration, the curves for the $\mathrm{ob} / \mathrm{ob}, \mathrm{db} / \mathrm{db}$, and gold thioglucose obese mice are proportionally decreased in comparison to the curves for the thin mice over the range of insulin concentration from 0.1 to $100 \mathrm{ng}$ per $\mathrm{ml}$. When the bound/free of the labeled hormone is expressed as a function of the bound hormone by the method of Scatchard (23), identically shaped curves are obtained for the thin and obese mice. (Fig. 2A, B, C). This type of curvilinear Scatchard plot reflects the continuously decreasing affinity of the insulin receptor population as the fractional saturation increases. This result would be expected with negative cooperativity as has been previously demonstrated for the insulin receptor interaction (24), but may also reflect, in part, two or more discrete populations of receptors, with different affinities (21). At the same fractional saturation, the slopes of the curves for the thin and obese mice are the same indicating that the apparent affinity is unaltered in the obese mice. It is clear that the decrease in insulin binding observed in the obese mice can be accounted for completely by the decrease in insulin receptor concentration as obtained from the intercept of the Scatchard plot at the abscissa (7).

In the presence of cooperativity, Hill's analysis (25, 26) provides a useful means of comparing average affinity and quantifying cooperative interactions. The Hill plots for the $\mathrm{db} / \mathrm{db}$ and gold thioglucose obese mice superimpose on the same line as the thin (Fig. 3 ) as has been previously shown for ob/ob mice (7). These data indicate that the average affinity and extent of cooperative interactions are the same which further supports the conclusion that the differences in insulin binding between the obese and thin animals is accounted for fully by differences in receptor concentration.

II. Insulin binding in thin mice heterozygous for the $o b$ gene $(o b /+)$. One group of thin mice known to 

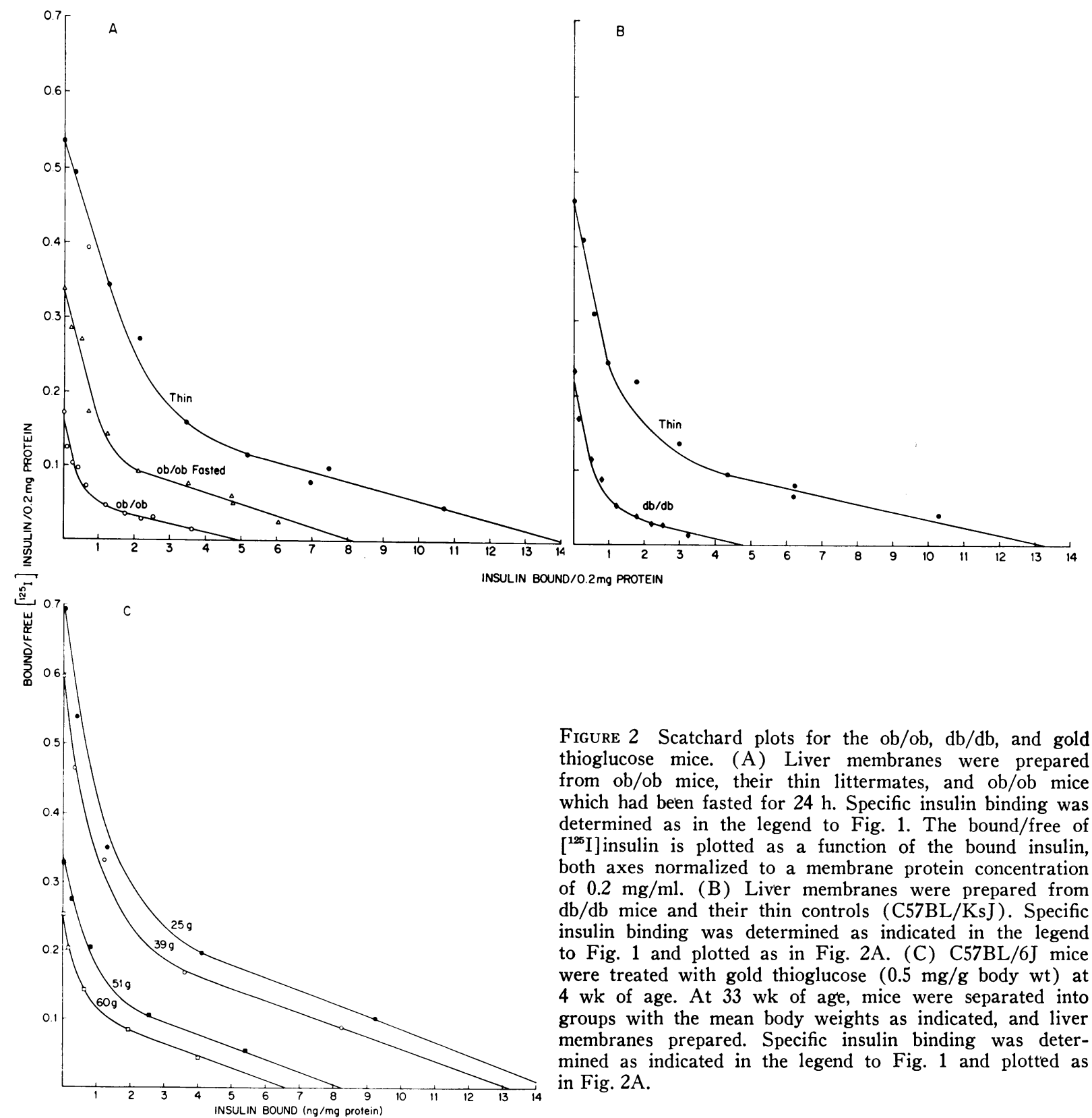

Figure 2 Scatchard plots for the ob/ob, db/db, and gold thioglucose mice. (A) Liver membranes were prepared from ob/ob mice, their thin littermates, and ob/ob mice which had been fasted for $24 \mathrm{~h}$. Specific insulin binding was determined as in the legend to Fig. 1. The bound/free of $\left[{ }^{25} \mathrm{I}\right]$ insulin is plotted as a function of the bound insulin, both axes normalized to a membrane protein concentration of $0.2 \mathrm{mg} / \mathrm{ml}$. (B) Liver membranes were prepared from $\mathrm{db} / \mathrm{db}$ mice and their thin controls (C57BL/KsJ). Specific insulin binding was determined as indicated in the legend to Fig. 1 and plotted as in Fig. 2A. (C) C57BL/6J mice were treated with gold thioglucose $(0.5 \mathrm{mg} / \mathrm{g}$ body wt) at $4 \mathrm{wk}$ of age. At $33 \mathrm{wk}$ of age, mice were separated into groups with the mean body weights as indicated, and liver membranes prepared. Specific insulin binding was determined as indicated in the legend to Fig. 1 and plotted as in Fig. 2A.

be heterozygous for the ob gene was studied. In this small group, no significant differences in body weight, plasma glucose, or insulin concentrations were found when compared to thin homozygous normals $(+/ t)$. Further, insulin binding to liver membranes (Fig. 1) and to thymic lymphocytes (data not shown) from these animals was indistinguishable from binding to these tissues of homozygous thin controls $(+/ t)$. In a large number of experiments, we have found no difference in insulin binding to liver membranes from the thin littermates (composed of two-thirds heterozygotes) when compared to homozygous normal. These data further suggest that the lowered insulin receptor concentration in the tissues of the ob/ob mouse is not the direct expression of the genetic defect, but rather relates to the obesity which these animals develop.

III. Effect of body weight and degree of obesity on insulin binding. To study the relationship between the degree of obesity, plasma insulin levels, and insulin binding, a group of gold thioglucose obese mice were separated into groups by weight. In these gold thioglucose obese mice, where sex and age of onset of 


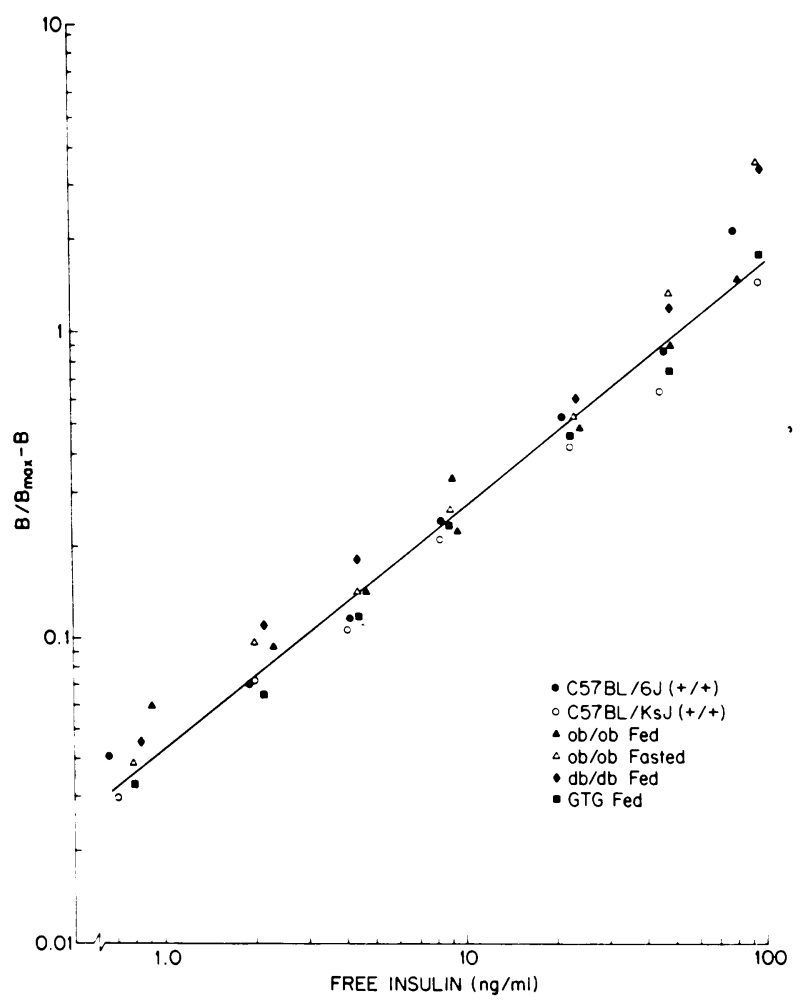

FIGURE 3 Hill plot analysis of the insulin-binding data. Specific insulin binding was determined to liver membranes from ob/ob, ob/ob fasted for $24 \mathrm{~h}, \mathrm{db} / \mathrm{db}$ (db/db-II in Table I), gold thioglucose obese (GTG-II in Table I), and thin $(\mathrm{C} 57 \mathrm{BL} / 6 \mathrm{~J}$ and $\mathrm{C} 57 \mathrm{BL} / \mathrm{KsJ})$ mice. Data were then plotted as $\log \left(B /\left[B_{\max }-B\right]\right)$ vs. the log-free insulin concentration (25), where $B$ is the insulin bound at the given insulin concentration. In theory, for a negatively cooperative system, $\mathrm{B}=\mathrm{B}_{\max }$ only when the free insulin concentration approaches infinity. Since the subtraction of nonspecific binding artifactually makes $B=B_{\max }$ for a finite value of free insulin, the Hill plot artifactually will approach a vertical asymptote at a finite value of $\log$ of free insulin concentration (43). Therefore, $B_{\max }$ was considered to be the specific binding at $250 \mathrm{ng}$ per $\mathrm{ml}$, since it is difficult to determine the exact contribution of nonspecific binding to total binding of $\left[{ }^{125} \mathrm{I}\right]$ insulin above this concentration. A single line fit the data for all of the groups of mice. The Hill coefficient is 0.80 . The average affinity or equilibrium constant for the insulin receptor interactions, producing half-maximal saturation of receptors, is $1.4 \times$ $10^{8} \mathrm{M}^{-1}$.

obesity are the same, the increase in body weight paralleled the increase in the degree of obesity. As body weight increased, IRI increased and insulin binding to liver membranes progressively and significantly fell (Fig. 4A). It is apparent that in this case there is a close inverse correlation $(r=-0.96, P<0.01)$ between the body weight, i.e. the degree of obesity, and the insulin binding (Fig. 4B). Again, Scatchard plots for the four groups of mice were identically shaped,
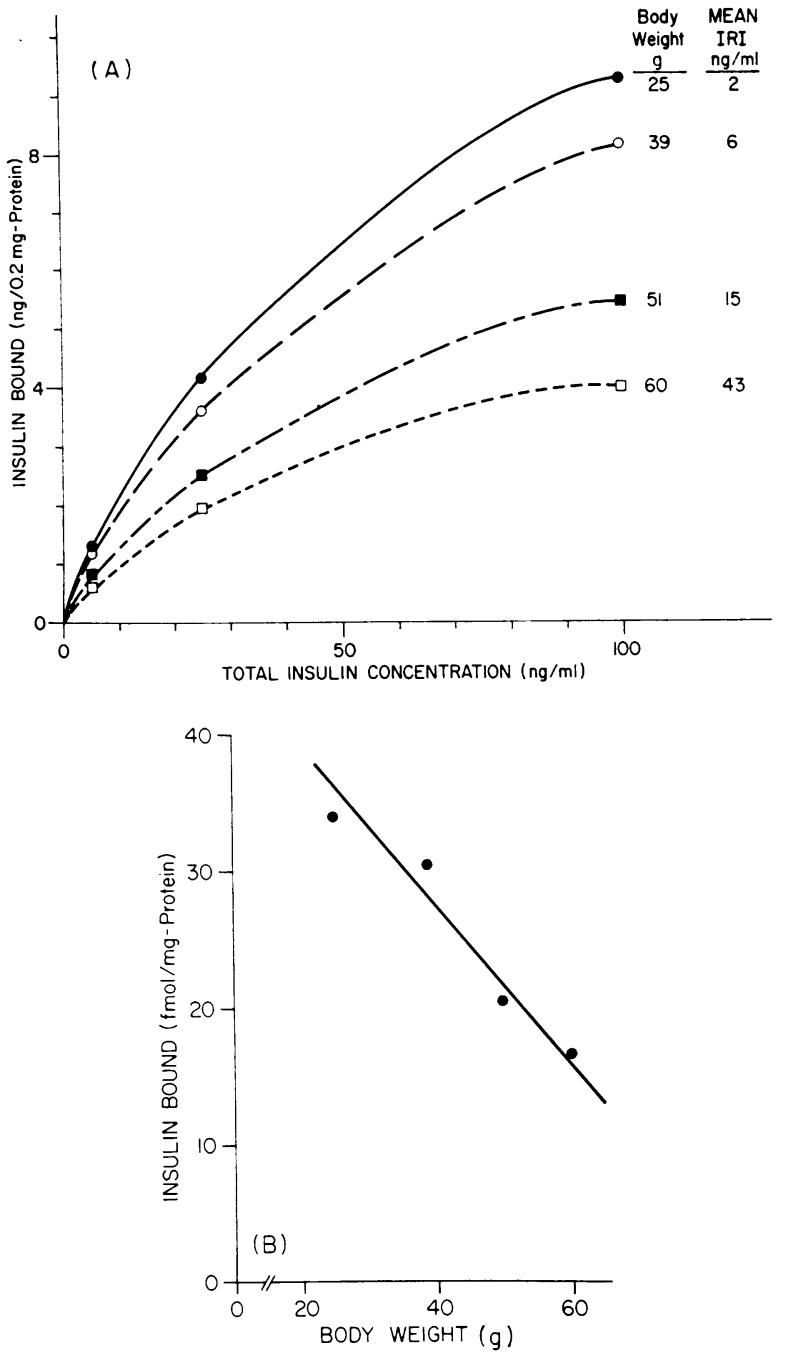

FIGURE 4 The effect of body weight and immunoreactive insulin on insulin binding in gold thioglucose obese mice. (A) Specific insulin binding was determined to liver membranes from the gold thioglucose mice described in Fig. 2C. The data are the mean of triplicate determinations in three experiments. Immunoreactive insulin levels were determined at the time of sacrifice and represent the mean of four to nine separate serum samples. The data on insulin binding for each group of animals is statistically different at each point from that of the other groups at the $P<0.05$ level, except for insulin binding at $5 \mathrm{ng}$ per $\mathrm{ml}$ in the 25and 39-g animals. These data were obtained on membrane preparations from completely separate groups of animals than those reported in Table I. (B) The insulin bound to liver membranes from gold thioglucose obese mice when the insulin concentration was $0.1 \mathrm{ng}$ per $\mathrm{ml}\left(1.6 \times 10^{-11} \mathrm{M}\right)$ has been plotted as a function of the mean body weight. Data are taken from Fig. 3C. The linear regression coefficient $r=-0.96$ which is significant at the $P<0.01$ level.

indicating that the decrease in binding is fully accounted for by a decrease in insulin receptor concentration (Fig. 2C).

Instilin Receptor Deficiency in Obesity 


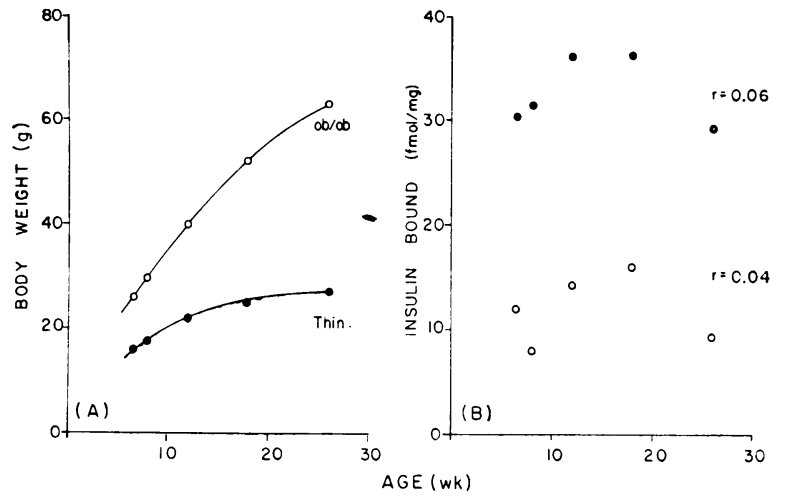

Figure 5 Correlation of age, body weight, and insulin binding for ob/ob and thin mice. (A) Mean body weight for five groups of paired ob/ob and thin mice are plotted as a function of age. (B) $\left[{ }^{125} \mathrm{I}\right]$ Insulin bound at an insulin concentration of $0.1 \mathrm{ng} / \mathrm{ml}\left(1.6 \times 10^{-11} \mathrm{M}\right)$ is given as a function of age in weeks for the same groups of thin and ob/ob mice as in Fig. 6A.

On the other hand, in the ob/ob mouse, the receptor deficiency showed little progression with increasing body weight (Fig. 5), presumably because of the severity of the obesity even at the earliest age studied. At the age of $2 \mathrm{wk}$, when body weight is still normal, it is possible to identify fat cell hypertrophy (27), and by the age of $3 \mathrm{wk}$, there is an increased proportion of body fat (28). Insulin binding to thymic lymphocytes is already significantly decreased by 4 wk of age (Table II). The smaller decrease in insulin receptors in thymic lymphocytes at $4 \mathrm{wk}$ compared to 6 and $8 \mathrm{wk}$ may reflect the lesser degree of obesity and insulin resistance at the younger age. Liver membranes show a marked decrease in receptors by $6 \mathrm{wk}$ of age, the earliest age studied using this tissue, and no further decline was evident over the next 20 wk (Fig. 5). The marked degree of obesity and hyperinsulinemia that has developed By $6 \mathrm{wk}$ is apparently sufficient to produce the maximal decrease in insulin receptors that is seen in obesity. Although the $60 \mathrm{~g}$ gold thioglucose obese mice are of similar weight to the heaviest ob/ob mice, the serum insulin concentrations are less markedly elevated and the decrease in insulin binding less pronounced (Figs. 4B and 5). It is probable that the very early onset of hypertrophy and hyperplasia in adipose tissue of the ob/ob mouse accounts for some of this difference.

Insulin binding to liver membranes of thin mice did not vary within the range of age and body weight studied (Fig. 5). The thin mice at 26 wk of age weigh $69 \%$ more than thin mice at 6 wk of age. These mice, by definition, are not obese, but merely represent the normal range for that age and their liver membranes bind the same amount of insulin as thin mice of younger age and lesser weight. Similarly, the previous failure of others (29) to find a decrease in insulin receptors in large fat cells as compared to small fat cells may be due to the fact that old animals were used to obtain the large fat cells, rather than agematched obese animals.

$I V$. The effect of dieting on insulin binding. To further evaluate the dynamics of the insulin receptor deficiency in obesity, two separate groups of mice that had become obese by gold thioglucose treatment were dieted to normal weight and compared to obese mice of similar initial weight, fed ad lib. In association with the weight loss, IRI concentrations returned to normal (Table I, Fig. 6). In one group of dieted gold thioglucose obese mice, binding returned to normal (Table I) ; in the second group, insulin binding increased substantially but remained slightly less than the insulin binding in their thin controls (Fig. 6).

In the ob/ob mice that were dieted, the abnormalities were reversed, but not to the same extent as the dieted gold thioglucose obese. When ob/ob mice are dieted to normal weight, their proportion of body fat remains grossly increased (30). Similarly, with reduction to normal body weight, the plasma insulin concentration in the ob/ob mice decreased but remained above the normal range (Table III), and insulin binding increased from 35 to $64 \%$ of control (Fig. 7). The persistent increase in IRI and in the proportion of body

TABLE II

Insulin Binding to Thymic Lymphocytes

\begin{tabular}{|c|c|c|c|c|c|}
\hline Age & & $\begin{array}{c}\text { Thin } \\
(+/+;+/ o b)\end{array}$ & & $\begin{array}{c}\text { Obese } \\
\text { (ob/ob) }\end{array}$ & \\
\hline$w k$ & $P$ value & & $P$ value & & $P$ value \\
\hline $4 \frac{1}{2}$ & NS & $\begin{array}{c}4.5 \pm 0.4 \\
(n=4)\end{array}$ & $\leftarrow<0.01-$ & $\begin{array}{c}3.2 \pm 0.4 \\
(n=3)\end{array}$ & $\leftarrow$ \\
\hline $6 \frac{1}{2}$ & $\overrightarrow{\mathrm{NS}}$ & $\begin{array}{c}3.5 \pm 0.5 \\
(n=4)\end{array}$ & $\leftarrow<0.02 \rightarrow$ & $\begin{array}{c}1.8 \pm 0.2 \\
(n=3)\end{array}$ & $\underbrace{}_{N S}$ \\
\hline $8 \frac{1}{2}$ & $\longrightarrow$ & $\begin{array}{c}4.2 \pm 0.5 \\
(n=4)\end{array}$ & $\leftarrow<0.05 \rightarrow$ & $\begin{array}{c}1.8 \\
(n=1)\end{array}$ & $\longleftarrow$ \\
\hline
\end{tabular}

$\mathrm{Ob} / \mathrm{ob}$ mice and thin littermates $(+/+; \mathrm{ob} /+)$ were killed by decapitation the thymus removed, and the cells freed by mechanical disruption. After separation from stroma by use of a nylon mesh, cells were incubated with [25I] insulin $\left(1.0 \mathrm{ng} / \mathrm{ml}\right.$ or $\left.1.7 \times 10^{-10} \mathrm{M}\right)$ for $90 \mathrm{~min}$ at $15^{\circ} \mathrm{C}$, separated by centrifugation, washed, and the radioactivity counted. Nonspecific binding was determined and subtracted. The data expressed as $\mathrm{fmol} / 10^{8}$ cells and are the mean $\pm \mathrm{SEM}$ for $n$ determinations each done in duplicate in each experiment. Cell counts were done in triplicate at two dilutions on a particle data analyzer and the insulin bound normalized to $10^{8}$ cells. The $P$ values represent the probability that both samples were drawn from a single population (the null hypothesis) and were determined by an unpaired $t$ test, with the exception of the data on the $8 \frac{1}{2}$-wk-old ob/ob mice. The latter experiment could only be successfully done once due to the difficulty in obtaining thymocytes in these animals. In this case the $P$ value is based on the probability that this single value lies within the $95 \%$ confidence limits of the group to which it is being compared. If the $P$ value was $>0.05$ it was considered nonsignificant (NS). 
TABLE III

Metabolic Data for ob/ob and Thin Mice Undergoing Food Restriction and Insulin Treatment

\begin{tabular}{|c|c|c|c|c|c|}
\hline \multirow[b]{2}{*}{ Experiment } & \multicolumn{2}{|c|}{ Mean body wt } & \multirow[b]{2}{*}{ Plasma glucose* } & \multirow[b]{2}{*}{ IRI* } & \multirow[b]{2}{*}{ Insulin bound* } \\
\hline & $\begin{array}{c}\text { Prediet } \\
\text { period }\end{array}$ & $\begin{array}{l}\text { Postdiet } \\
\text { period }\end{array}$ & & & \\
\hline & & $g$ & $\mathrm{mg} / 100 \mathrm{ml}$ & $n g / m l$ & $\mathrm{fmol} / \mathrm{mg}$ protein \\
\hline I. ob/ob Fed & 28.2 & $51.1 \pm 1.9$ & $196 \pm 4$ & $110 \pm 10$ & $12.0 \pm 2.0$ \\
\hline ob/ob Dieted $\ddagger$ & 31.6 & $26.3 \pm 1.1$ & $140 \pm 45$ & $6.6 \pm 0.9$ & $17.5 \pm 2.8$ \\
\hline Thin littermates & 16.1 & $27.6 \pm 0.7$ & $133 \pm 10$ & $1.8 \pm 0.4$ & $27.6 \pm 1.2$ \\
\hline II. ob/ob Fed & - & $40.5 \pm 1.8$ & $252 \pm 62$ & $108 \pm 17$ & $9.3 \pm 1.6$ \\
\hline ob/ob Fasted§ & 34.0 & $39.0 \pm 1.3$ & $74 \pm 12$ & $3.7 \pm 0.6$ & $18.5 \pm 1.4$ \\
\hline \multicolumn{6}{|l|}{ III. ob/ob Fasted $\S+$ insulin $\times 24 \mathrm{~h}$} \\
\hline $48 \mathrm{U}$ & - & - & $57 \pm 14$ & $3,700 \pm 1,400$ & $10.1 \pm 0.6$ \\
\hline $24 \mathrm{U}$ & 39.7 & - & $31 \pm 9$ & $1,380 \pm 161$ & $11.2 \pm 1.3$ \\
\hline $6 \mathrm{U}$ & 34.0 & $31.9 \pm 0.7$ & $25 \pm 15$ & $422 \pm 95$ & $12.1 \pm 0.6$ \\
\hline $2 \mathrm{U}$ & 39.7 & $36.9 \pm 0.9$ & $74 \pm 30$ & $8.7 \pm 3.5$ & $19.2 \pm 3.6$ \\
\hline $1 \mathrm{U}$ & 39.7 & $36.7 \pm 0.8$ & $77 \pm 11$ & $3.8 \pm 0.3$ & $19.2 \pm 2.0$ \\
\hline IV. ob/ob Fasted + insulin $\times 1 \mathrm{~h}$ & 35.3 & $31.2 \pm 1.5$ & $62 \pm 18$ & $7,180 \pm 870$ & $15.2 \pm 0.6$ \\
\hline V. Thin fed & - & $24.5 \pm 0.8$ & $132 \pm 8$ & $1.0 \pm 0.2$ & $29.1 \pm 1.6$ \\
\hline Thin fasted & 24.5 & $22.0 \pm 0.8$ & $68 \pm 11$ & $0.7 \pm 0.1$ & $34.5 \pm 1.1$ \\
\hline
\end{tabular}

* Plasma glucose, insulin, and insulin bound were measured at the end of the diet period.

$\ddagger$ ob/ob mice were dieted as indicated in the legend to Fig. 7 .

$\S$ The regiment for fasting and insulin therapy is indicated in the legend to Fig. 8.

fat is consistent with the failure of insulin binding to return completely to normal. There is a possibility that this residual defect in insulin binding results from a separate genetic contribution to the decreased number of receptors, however, this seems unlikely in view of the findings of normal binding in the heterozygotes.

To test the effect of acute dietary restruction, four groups of ob/ob mice were fasted for $24 \mathrm{~h}$ during which they lost an average of $4 \mathrm{~g}$. Plasma insulin decreased from an average of 108-3.6 $\mathrm{ng}$ per $\mathrm{ml}$ while plasma glucose fell from 252 to $74 \mathrm{mg}$ per $100 \mathrm{ml}$ (Table III). With fasting, insulin binding increased from an average of $33-65 \%$ of normal (Fig. 8A). This increase in binding was associated with an increase in the number of receptors rather than a change in affinity (Fig. 2A). Note that fasting produces the same change in IRI and insulin binding as chronic diet restriction, but with a much smaller changes in body weight and fat stores. Two groups of thin mice were also fasted for $24 \mathrm{~h}$, during which time the plasma insulin concentrations decreased from 1.0 to $0.7 \mathrm{ng}$ per $\mathrm{ml}$, and insulin binding increased by a small but consistent increment to $120 \%$ of control (Table III and Fig. 8A).

$V$. The effect of sustained hyperinsulinemia on insulin binding in obesity. When all the data sited thus far are analyzed, a striking correlation is found between the insulin receptor concentration and the insulin con- centration in plasma (Fig. 9). To investigate further the role of the plasma insulin concentration on insulin binding, the fall in plasma insulin concentration that normally occurs in faster ob/ob mice was prevented by administration of insulin. In three groups of ob/ob mice given 6,12 , and $48 \mathrm{U}$ of $\mathrm{NPH}^{\circledR}$ insulin over a 24-h period, IRI levels at the time of sacrifice were $440,1,380$, and $3,770 \mathrm{ng}$ per $\mathrm{ml}$, respectively. In liver membranes prepared from these mice, insulin binding did not increase as had been observed with fasting alone, but rather remained at a level indistinguishable from that observed in fed ob/ob mice (Fig. 8B). Thus, the binding defect persisted despite the weight loss and fall in blood glucose. In ob/ob mice given 1 and $2 \mathrm{U}$ of $\mathrm{NPH}$ insulin over the $24-\mathrm{h}$ period of fasting, insulin concentrations were not significantly higher than animals fasted but not given insulin (Table III). In both of these groups of mice, insulin receptors increased to a level equal to that observed in ob/ob fasted for the same period of time but not given insulin. A final group of ob/ob mice fasted for $24 \mathrm{~h}$ received $4 \mathrm{U}$ of regular insulin $1 \mathrm{~h}$ before sacrifice, resulting in insulin concentrations of $7,180 \mathrm{ng}$ per $\mathrm{ml}$ (Table III); in spite of this marked acute hyperinsulinemia, insulin binding was only slightly decreased from the level observed in the fasted ob/ob mice (Fig. 8B). Thus, chronic hyperinsulinemia is associated with a decreased 


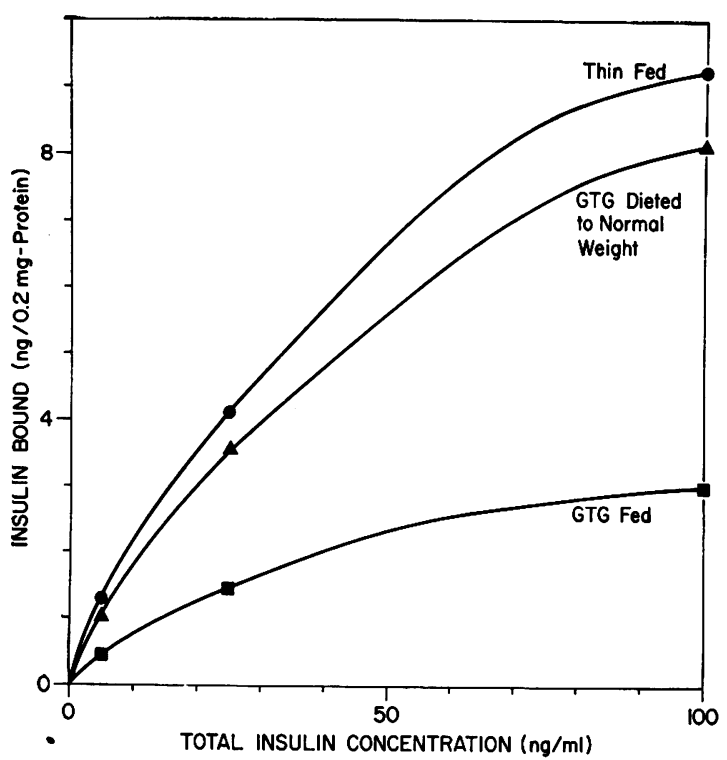

Figure 6 Effect of food restriction on insulin binding in gold thioglucose-induced obesity. Gold thioglucose obese mice from the group described in Fig. 2A were divided at an age of 33 wk into two groups each with a mean weight of $53 \mathrm{~g}$. The mice designated GTG fed had free access to food, and at the time of killing at 38 wk weighed $59 \mathrm{~g}$ and had a mean IRI of $36.6 \pm 5.9 \mathrm{ng} / \mathrm{ml}$. The group designated GTG dieted to normal weight were restricted to $4 \mathrm{~g}$ of Purina Rat Chow daily and weighed $24 \mathrm{~g}$ at the time of killing, with IRI of $1.7 \pm 0.1 \mathrm{ng} / \mathrm{ml}$. The thin mice weighed $24 \mathrm{~g}$ and had IRI of $2.0 \pm 1.2 \mathrm{ng} / \mathrm{ml}$. Specific $\left[{ }^{25} \mathrm{I}\right]$ insulin binding to liver membranes was determined as in Fig. 1. The data are the mean of triplicate determination in three experiments.

insulin binding of obesity, while acute hyperinsulinemia has little or no effect $(4,5,31)$.

$V I$. Comparison of insulin degradation and insulin binding. In previous studies we have shown that binding and degradation of $\left[{ }^{125} \mathrm{I}\right]$ insulin by liver membranes are separate processes (17). With liver membranes from the three types of obese mice, both fed and dieted, there is no correlation between the degradation and binding of $\left[{ }^{208} \mathrm{I}\right]$ insulin (Fig. 10). Degradation of labeled hormone is somewhat less rapid in the obese mice than thin controls, as has been reported for the ob/ob mouse (7). The differences in degradation are small compared to the differences in binding, and correction of results for degradation, if anything, slightly increases the defect in binding observed. These data also provide further support for the independence of insulin binding and degradation.

\section{DISCUSSION}

Decreased insulin binding appears to be a common feature of the insulin resistance of the obese state. Previons studies have shown that in the ob/ob mouse, insulin binding is decreased to surface receptors on liver $(4,5)$, fat (8), thymic lymphocytes (10), and muscle (9). A decreased concentration of receptors fully accounts for this decrease in insulin binding; the receptor in the ob/ob mouse is normal in its ability to interact with insulin and in its cooperative interactions (7). Similarly, there is a decrease in insulin binding to liver membranes from $\mathrm{db} / \mathrm{db}$ and New Zealand Obese (NZO) mice (33), two other inherited syndromes characterized by obesity, hyperinsulinemia, and insulin resistance. NZO mice differ from the ob/ob and $d b / d b$ mice in that their inheritance is polygenic, with variable penetrance, rather than autosomal recessive (1). Decreased insulin receptors are also found in liver membranes from normal mice made obese by gold thioglucose and on circulating mononuclear cells (31) and fat cell membranes (34) from obese human subjects. Taken together, these data indicate that the decreased insulin binding is a common feature of the insulin resistance of obesity.

The failure of Livingston, Cuatrecasas, and Lockwood (29) to demonstrate a change in insulin binding

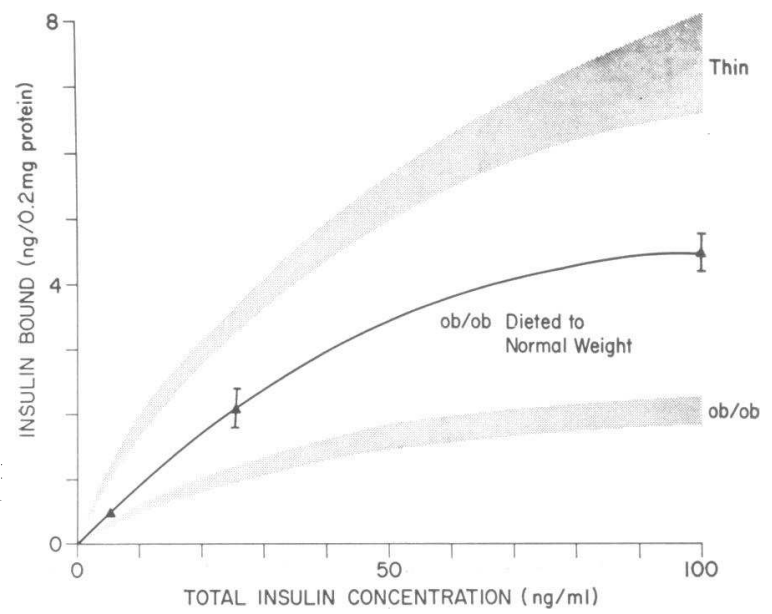

FIGURE 7 Effect of dieting to normal weight on insulin binding in ob/ob mice. 6-wk-old ob/ob mice weighing an average of $28.0 \mathrm{~g}$ were fed ad lib. and killed at an age of $18 \mathrm{wk}$, at which time their weight was $51 \mathrm{~g}$. A second group of ob/ob mice of the same age and weight were restricted to $2 \mathrm{~g}$ of Purina Rat Chow daily and sacrificed at an age of $18 \mathrm{wk}$ weighing an average of $26 \mathrm{~g}$. Agematched thin mice were fed ad lib and attained an average weight of $26 \mathrm{~g}$. In Table III these three groups are designated respectively ob/ob fed, ob/ob dieted, and thin littermates. The specific insulin binding to liver membranes of the three groups was determined and corrected for membrane concentration. The data for the ob/ob-dieted group $(\Delta)$ are the mean of triplicate determinations in four experiments. The data for both the ob/ob-fed and thin-fed mice fell within the range of the ob/ob and thin mice in Fig. 1 and therefore these latter data are shown for comparison. 


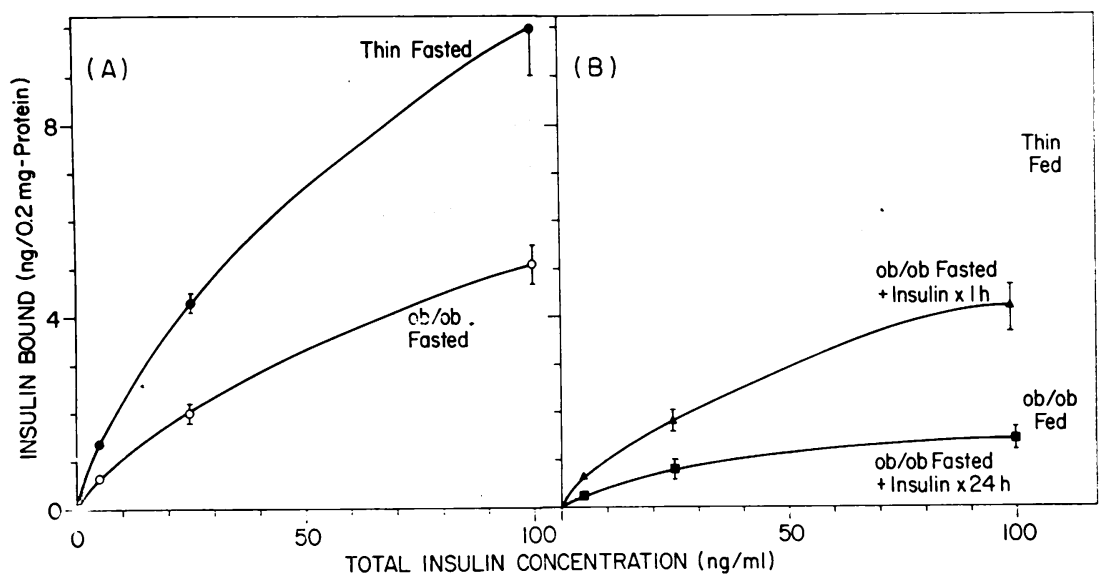

FIgURE 8 The effect of fasting and the effect of acute and sustained hyperinsulinemia on insulin binding. (A) ob/ob and thin mice were fasted for $24 \mathrm{~h}$. Mean body weight, plasma glucose, and IRI are given in Table III. Specific $\left.{ }^{125} \mathrm{I}\right]$ insulin binding was determined as in Fig. 1. The data are the mean of triplicate determinations in four experiments on two preparations of membranes from the thin-fasted mice and the mean of nine experiments on four preparations from the ob/ob-fasted mice. The data for the thin-fed and ob/ob-fed mice that were age- and sex-matched with the fasted mice fell within the range of their respective groups in Fig. 1, and therefore these latter data are used for comparison. (B) ob/ob mice fasted for $24 \mathrm{~h}$ were given subcutaneous injections of NPH insulin at the start of the fast and after $12 \mathrm{~h}$ of fasting. In three groups of mice so treated with 6,24 , and $48 \mathrm{U}$ of insulin, respectively (Table III), specific insulin binding ( $\boldsymbol{a}$ ) was in the range of the ob/ob fed mice. The data for these three groups were not statistically different and therefore, have been combined and expressed as the mean \pm SEM for a total of seven experiments. Insulin binding was also determined in a group of ob/ob mice fasted $24 \mathrm{~h}$ and given $4 \mathrm{U}$ regular insulin $1 \mathrm{~h}$ before killing (Table III). These data are the mean \pm SEM of triplicate determinations in four experiments $(\boldsymbol{A})$.

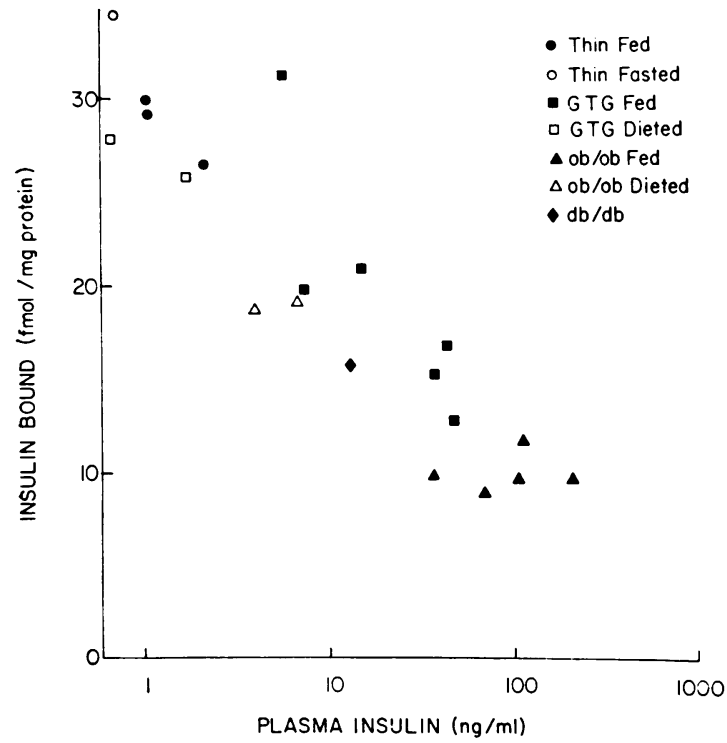

FIGURE 9 The correlation of insulin binding and hyperinsulinemia. The amount of insulin bound (expressed as femtomoles per milligram membrane protein) at an insulin concentration of $0.1 \mathrm{ng} / \mathrm{ml}\left(1.7 \times 10^{-11} \mathrm{M}\right)$ plotted for the indicated groups as a function of their mean plasma insulin concentrations at the time of sacrifice. to isolated adipocytes from rats of increasing weight may reflect differences in receptor regulation among target tissues or differences among the models of "obesity" which have been studied. Although little information is given about their animal model, it appears that they have compared insulin binding to adipocytes obtained from animals of different age and thus different weight. Since obesity is weight excess due to accumulation of fat beyond the normal range for a given age and sex, by definition, older, and therefore larger, animals are not necessarily obese unless they exceed the normal weight range for that age. In all studies presented here, age- and sex-matched controls were used. Within the limits of this study, we found no effect of age on insulin binding to liver membranes (similar to their findings with adipocytes), although aging may be associated with a decrease in insulin sensitivity of target tissues, especially when tested in vitro (29).

The finding of normal binding to liver membranes and thymocytes of mice heterozygote for the ob gene provides evidence that the decreased insulin binding in the ob/ob mouse is a result of the obesity and not the primary genetic defect. However, it is still possible that in these animals there is a genetic contribution too

Insulin Receptor Deficiency in Obesity 


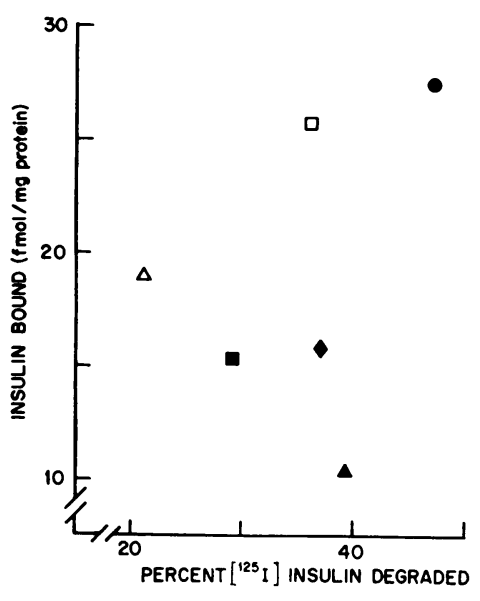

Figure 10 Independence of insulin binding and insulin degradation. $\left[{ }^{125} \mathrm{I}\right]$ Insulin was incubated for $6 \mathrm{~h}$ at $20^{\circ} \mathrm{C}$ with three concentrations of liver membranes from the mice indicated. The supernatant was removed and the percentage of counts that bound to cultured human lymphocytes (IM 9) during a subsequent $15^{\circ} \mathrm{C}, 90$-min incubation was determined (see reference 32 for details). The percentage of hormone degraded was calculated by comparing the percent of counts of $\left.{ }^{125} \mathrm{I}\right]$ insulin that bound to cultured lymphocytes before and after incubation with liver membranes. The insulin bound at $0.2 \mathrm{mg}$ of membrane protein per $\mathrm{ml}$ was then plotted as a function of the insulin degraded at the same membrane concentration. The symbols used for each group of membranes studied are the same as in Fig. 10.

small to detect or that in one or more other forms of genetic obesity, a primary defect in the insulin receptors or its regulation might exist. A primary defect in insulin receptors, through a mechanism such as a decrease in sensitivity of the hypothalamic satiety center to insulin $(35,36)$, could initiate hyperphagia and all of the subsequent metabolic manifestations of obesity.

The effect of degree of obesity on insulin binding was evaluated in normal mice made obese by gold thioglucose. In this instance, as the body weight and the proportion of body fat increases, there is a rise in the IRI concentrations in plasma and a decrease in the insulin receptor concentration in liver membranes. This effect of increasing body weight on insulin binding was not evident in the ob/ob mouse, except possibly for the experiments with thymic lymphocytes from $4 \frac{1}{2}$-wk-old mice, probably because of the very early age of onset of the obesity $(27,28)$. By $6 \mathrm{wk}$ of age, the obesity and its concomitant metabolic alterations have already caused the maximal decrease in the insulin receptor concentration that is seen in this setting.

Factors involved in regulation of the insulin receptor in obesity may be multiple. In gold thioglucose obese mice, diet restriction to normal weight was accompanied by a return of plasma glucose, plasma insulin, and insulin binding to normal or near normal levels.
In contrast, in the ob/ob mice that were food restricted to normal weight, IRI fell and insulin binding increased, but both failed to reach normal levels. The failure of the insulin receptor concentration and IRI to return to normal may result from the persistent increase in the proportion of body fat or possibly a separate, albeit small, genetic contribution to the receptor defect. It is of interest that fasting of ob/ob mice for $24 \mathrm{~h}$ caused a fall in IRI and an increase in the insulin receptor concentration in liver membranes similar to that seen with chronic diet restriction, in spite of a much smaller change in weight. Obviously, it is difficult to compare exactly the insulin binding data in all animals with each of the various metabolic parameters. When the data on all of the animal models of obesity are considered, however, there is a very striking correlation between the insulin receptor concentration and the plasma insulin concentration (Fig. 9). With the exception of the gold thioglucose obese mice, no consistent correlation was found between insulin binding and body weight, degree of obesity, or plasma glucose.

The effect of plasma insulin on the insulin receptor concentration was evident when fasting ob/ob mice were given exogenous insulin to maintain their hyperinsulinemia. In these mice the increase in the insulin receptor concentration normally seen with fasting was prevented, despite the weight loss and fall in blood glucose. In the fasted ob/ob mice, given doses of insulin over the $24-\mathrm{h}$ period which did not elevate the IRI, insulin binding increased as occurred with fasting only. This suggested that it was the persistent elevation in plasma insulin concentration that accounted for the decrease in binding. Whether this is a direct effect of insulin or is mediated through a chain of metabolic events triggered by insulin is uncertain.

Evidence for a direct regulatory effect of insulin on its own receptor also comes from other in vivo and in vitro studies. Using human lymphocytes, Gavin, Roth, Neville, DeMeyts, and Buell showed that cells cultured in media containing insulin had a decrease in the insulin receptor concentration (37). The magnitude of the decrease in insulin binding and the time-course of the decrease was dependent on the insulin concentration in the culture media. Furthermore, when insulin was removed from the culture media, receptors reappeared after 12-24 $\mathrm{h}$ and the reappearance could be blocked by inhibitors of protein synthesis (38). Similarly, Mahler and Szabo (39) showed that ob/ob mice became more insulin sensitive after alloxan therapy which decreased endogenous insulin. From these data and those of the present study, it appears that insulin regulates the concentration of its own receptor by some type of negative feedback control and that sustained hyperinsulinemia 
induced by obesity or high caloric intake is probably the factor that causes a decrease in insulin binding. The exact mechanism of this regulation is a point for further investigation.

In the present study, we have shown that decreased binding is a common feature of the insulin resistance of obesity, and presented data that indicates that sustained hyperinsulinemia is probably a major factor regulating the insulin receptor concentration. The interaction of insulin with its surface receptor is, however, only the first step in hormone action; cellular response to hormone also involves a cascade of metabolic events after the surface binding of hormone. Obviously, regulation of cellular response to hormone can be exerted at other points along this pathway. We suggest that in the insulin resistance of obesity, the decreased insulin binding accounts, at least in part, for the insulin insensitivity. Food restriction causes an increase in insulin sensitivity both in vivo and in vitro $(1,2,40)$ and a decrease in circulating insulin concentration. The concomitant increase in insulin binding may play an important role in determining the increased cellular response to hormone. During the acute fast, the in vitro and in vivo studies in insulin sensitivity of fat or muscle (41) do not show the increase in insulin binding. The lack of correlation between the insulin binding data and the cellular response to hormone indicate that subsequent regulatory steps may be rate limiting under these circumstances or that the insulin receptor interaction in vivo may be altered due to factors such as acidosis (42) or that the rate of regulation of the receptor in liver is different from that in muscle and fat. Nonetheless, the insulin receptor interaction is an important regulatory step in determining cellular response to hormone. These studies indicate that the insulin receptor concentration is not fixed and that the concentration of circulating insulin is a major factor controlling the concentration of receptors.

\section{ACKNOWLEDGMENTS}

We thank Carla M. Hendricks, James Boone, and William Hardy for their excellent technical assistance and Doctors Phillip Gorden, Ira D. Goldfine, James R. Gavin, III, and Pierre DeMeyts for helpful advice during the course of these studies. We also wish to thank Carol Shinn for excellent secretarial assistance.

\section{REFERENCES}

1. Stauffacher, W., L. Orci, D. P. Cameron, I. M. Burr, and A. E. Renold. 1971. Spontaneous hyperglycemia and/or obesity in laboratory rodents: an example of the possible usefulness of animal disease models with both genetic and environmental components. Recent Prog. Horm. Res. 27: 41-95.

2. Rabinowitz, D. 1970. Some endocrine and metabolic aspects of obesity. Annu. Rev. Med. 21: 241-258.
3. Roth, J. 1973. Peptide hormone binding to receptors: a review of direct studies in vitro. Metab. (Clin. Exp.). 22: 1059-1073.

4. Kahn, C. R., D. M. Neville, Jr., P. Gorden, P. Freychet, and J. Roth. 1972. Insulin receptor defect in insulin resistance: studies in the obese-hyperglycemic mouse. Biochem. Biophys. Res. Commun. 48: 135-142.

5. Kahn, C. R., D. M. Neville, Jr., and J. Roth. 1973 Insulin-receptor interaction in the obese-hyperglycemic mouse: a model of insulin resistance. J. Biol. Chem. 248: $244-250$

6. Mahler, R. J., P. W. Mobley, and P. U. Dubuc. 1974 Increased gluconeogenesis in the ob/ob mouse-a previously undefined parameter of insulin resistance. Endocrinology. 94(Suppl.): 236. (Abstr.)

7. Soll. A. H., C. H. Kahn, and D. M. Neville, Jr. 1975. The decreased insulin binding to liver plasma membranes in the obese hyperglycemic mouse (ob/ob): demonstration of a decreased number of functionally normal receptors. J. Biol. Chem. 250: 4702-4707.

8. Freychet, P., M. H. Laudat, P. Laudat, G. Rosselin, C. R. Kahn, P. Gorden, and J. Roth. 1972. Impairment of insulin binding to fat cell plasma membrane in the obese hyperglycemic mouse. FEBS (Fed. Eur. Biochem. Soc.) Lett. 25 : 339-342.

9. Freychet, P., and E. Forgue. 1974. Insulin receptors in the heart muscle: impairment of insulin binding to the plasma membrane in the obese hyperglycemic mouse. Diabetes. 23 (Suppl. 1) : 354. (Abstr.)

10. Soll, A. H., I. D. Goldfine, J. Roth, C. R. Kahn, and D. M. Neville, Jr. 1974. Thymic lymphocytes in obese (ob/ob) mice: A mirror of the insulin receptor defect in liver and fat. J. Biol. Chem. 249: 4127-4130.

11. Coleman, D. L., and K. P. Hummel. 1967. Studies with the mutation, diabetes, in the mouse. Diabetologia. 3: 238-248.

12. Marshall, N. B., R. G. Barrnett, and J. Mayer. 1955 Hypothalamic lesions in gold thioglucose injected mice. Proc. Soc. Exp. Biol. 90: 240-244.

13. Washko, M. E., and E. W. Rice. 1961. Determination of glucose by an improved enzymatic procedure. Clin. Chem. 7: 542-545.

14. Roth, J., P. Gorden, and I. Pastan. 1968. "Big insulin": a new component of plasma insulin detected by radioimmunoassay. Proc. Natl. Acad. Sci. U. S. A. 61: $138-142$.

15. Neville, D. M., Jr. 1968. Isolation of an organ specific protein from cell-surface membrane of rat liver. Biochim. Biophy's. Acta. 154: 540-552.

16. Neville, D. M., Jr., and C. R. Kahn. 1974. Isolation of plasma membranes for cell surface membrane receptor studies. In Methods in Molecular Biology: Subcellular Particles, Structures and Organelles. A. I. Laskin and J. A. Last, editors. Marcel Dekker Inc., New York. $5: 57-88$.

17. Freychet, P., C. R. Kahn, J. Roth, and D. M. Neville, J. 1972. Insulin interactions with liver plasma membranes: independence of binding of the hormone and its degradation. J. Biol. Chem. 247: 3953-3961.

18. Hunter, W. M., and F. C. Greenwood. 1962. Preparation of iodine-131 labelled human growth hormone of high specific activity. Nature (Lond.). 194: 495-496.

19. Yalow, R. S., and S. A. Berson. 1960. Immunoassay of endogenous plasma insulin in man. J. Clin. Invest. 39 : 1157-1175.

20. Freychet, P., J. Roth, and D. M. Neville, Jr. 1971. Monoiodoinsulin: demonstration of its biological activity

Insulin Receptor Deficiency in Obesity 
and binding to fat cells and liver membranes. Biochem. Biophys. Res. Commun. 43: 400-408.

21. Kahn, C. R., P. Freychet, D. M. Neville, Jr., and J. Roth. 1974. Quantitative aspects of the insulin-receptor interaction in liver plasma membranes. J. Biol. Chem. 249 : 2249-2257.

22. Lowry, O. H., N. J. Rosebrough, A. L. Farr, and R. J. Randall. 1951. Protein measurement with the Folin reagent. J. Biol. Chem. 193: 265-275.

23. Scatchard, G. 1949. The attraction of proteins for small molecules and ions. Ann. N. Y. Acad. Sci. 51: 660-672.

24. DeMetys, P., J. Roth, D. M. Neville, Jr., J. R. Gavin, III, and M. A. Lesniak. 1973. Insulin interactions with its receptors: Experimental evidence for negative cooperativity. Biochem. Biophys. Res. Commun. 55: 154 161.

25. Hill, A. V. 1913. The combinations of haemoglobin with oxygen and with carbon monoxide. I. Biochem. J. $7: 471-480$.

26. Whitehead, E. 1970. The regulation of enzyme activity and allosteric transition. Prog. Biophys. Mol. Biol. 21 : 321-397.

27. Joosten, H. F. P., and P. H. W. van der Kroon. 1974. Enlargement of epididymal adipocytes in relation to hyperinsulinemia in obese hyperglycemic mice (ob/ob). Metab. (Clin. Exp.). 23: 59-66.

28. Chlouverakis, C., E. F. Dade, and R. A. L. Batt. 1970. Glucose tolerance and time sequence of adiposity, hyperinsulinemia and hyperglycemia in obese hyperglycemic mice (ob/ob). Metab. (Clin. Exp.). 19: 687-623.

29. Livingston, J. N., P. Cuatrecasas, and D. H. Lockwood. 1972. Insulin insensitivity of large fat cells. Science (Wash. D. C.). 177: 626-628.

30. Alonso, L. G., and T. H. Maren. 1955. Effect of food restriction on body composition of hereditary obese mice. Am. J. Physiol. 183: 284-290.

31. Archer, J. A., P. Gorden, and J. Roth. 1975. Defect in insulin binding to receptors in obese man. J. Clin. Invest. $55: 166-174$.

32. Gavin, J. R., III, J. Roth, P. Jen, and P. Freychet. 1972. Insulin receptors in human circulating cells and fibroblasts. Proc. Natl. Acad. Sci. U. S. A. 69: 747-751.

33. Baxter, D., R. J. Gates, and N. R. Lazarus. 1973. Insulin receptor of the New Zealand obese mouse
(NZO): changes following the implantation of islets of Langerhans. 8th Congress of the International Diabetes Federation. Excerpta Med. Int. Congr. Ser. 280: 161. (Abstr.)

34. Marinetti, G. V., L. Shatz, and K. Reilly. 1972. Hormone-membrane interactions. In Insulin Action. I. B. Fritz, editor. Academic Press, Inc., New York. 207-276.

35. Debons, A. F., I. Krimsky, A. From, and R. J. Cloutier. 1969. Rapid effects of insulin on the hypothalamic satiety center. Am. J. Physiol. 217: 1114-1118.

36. Baile, C. A., M. G. Herrera, and J. Mayer. 1970. Ventromedial hypothalamus and hyperphagia in hyperglycemic obese mice. Am. J. Physiol. 218: 857-863.

37. Gavin, J. R., III, J. Roth, D. M. Neville, Jr., P. DeMeyts, and D. N. Buell. 1974. Insulin-dependent regulation of insulin receptor concentrations: a demonstration in cell culture. Proc. Natl. Acad. Sci. U. S. A. $71: 84-88$.

38. Lesniak, M. A., A. R. Bianco, J. Roth. and J. R. Gavin, III. 1974. Regulation by hormone of its receptors on cells: Studies with insulin and growth hormone. Clin. Res. 22: 343A. (Abstr.)

39. Mahler, R. J., and O. Szabo. 1971. Amelioration of insulin resistance in obese mice. Am. J. Physiol. 221: 980-983.

40. Chlouverakis, C., and P. A. White. 1969. Obesity and insulin resistance in the obese-hyperglycemic mouse (ob/ob). Metab. (Clin. Exp.). 18: 998-1006.

41. Abraham, R. R., and A. Beloff-Chain. 1971. Hormonal control of intermediary metabolism in obese hyperglycemic mice. I. The sensitivity and response to insulin in adipose tissue and muscle in vitro. Diabetes. 20: $522-534$.

42. Kahn, C. R., A. H. Soll, D. M. Neville, Jr., I. D. Goldfine, J. A. Archer, P. Gorden, and J. Roth. The insulin receptor in obesity and other states of altered insulin sensitivity. Conference in Obesity, 1-3 October 1973. G. Bray, editor. Fogarty International Center Proceedings, Bethesda, Md. In press.

43. De Meyts, P. 1975. Insulin and growth hormone receptors in human cultured lymphocytes and peripheral blood monocytes. In Methods in Receptor Research. M. Blecher, editor. Marcel Dekker, Inc., New York. In press. 